\title{
eLyra
}

Fabrício Corsaletti

\section{POEMA CHINÊS COM PRESENTE DE ÍNDIO}

bato na porta da mulher que ama os livros

com uma garrafa de vinho

e uma antologia de poemas chineses

em português de Portugal

ela diz que só consegue saber

se um poema presta de verdade

depois de trepar

"através de inúmeros vales e montanhas chego às portas de Chu

ainda está lá a aldeia onde nasceu e cresceu a Dama Luminosa"

Dama Luminosa

da próxima vez

quero trazer uma bandeja de ouro e gengibre 